\title{
STRUCTURAL AND MASS SPECTROMETRIC CHARACTERISATION OF THE DINUCLEAR PLATINUM(II) SELENIDO-PHENYLSELENOLATO COMPLEX $\left[\mathrm{Pt}_{2}(\mu-\mathrm{Se})(\mu-\mathrm{SePh})\left(\mathrm{PPh}_{3}\right)_{4}\right] \mathbf{P F}_{6}$
}

\author{
R.G. Fortney-Zirker, W. Henderson, B.K. Nicholson \\ Department of Chemistry, University of Waikato, Hamilton, New Zealand \\ E-mail: w.henderson@waikato.ac.nz \\ Received November, 27, 2013 \\ The reaction of $\left[\mathrm{Pt}_{2}(\mu-\mathrm{Se})_{2}\left(\mathrm{PPh}_{3}\right)_{4}\right]$ with diphenyliodonium bromide gave $\left[\mathrm{Pt}_{2}(\mu-\mathrm{Se})(\mu-\mathrm{SePh})\right.$. \\ $\left.\cdot\left(\mathrm{PPh}_{3}\right)_{4}\right]^{+}$through arylation of a selenide ligand. The complex is characterised by ${ }^{31} \mathrm{P} \mathrm{NMR}$ \\ spectroscopy, elemental microanalysis, ESI mass spectrometry, and a single crystal X-ray dif- \\ fraction study, which showed the four-membered $\left\{\mathrm{Pt}_{2} \mathrm{Se}_{2}\right\}$ ring to be slightly puckered.
}

DOI: $10.15372 /$ JSC20150417

Ke yw or d s: platinum complexes, dinuclear complexes, selenide ligand, phenylselenolato ligand, arylation, crystal structure, electrospray mass spectrometry.

Dinuclear platinum(II) sulfide complex $\left[\mathrm{Pt}_{2}(\mu-\mathrm{S})_{2}\left(\mathrm{PPh}_{3}\right)_{4}\right]$ 1a [1] and analogues with alternative phosphine [2,3] or arsine [4] ligands have been extensively investigated over a considerable length of time [5] because of the rich and diverse chemistry they display. Reactivity includes alkylation $[6,7]$ and arylation $[8,9]$ reactions (generating platinum-thiolate complexes), redox chemistry $[10,11]$, metalloligand chemistry (whereupon one or both sulfide ligands coordinate to metal centres generating sulfide-bridged homo- [12] and hetero- [13 ] metallic aggregates), and interesting ligandbased reactivity [14].

In contrast, the chemistry of selenide analogue $\left[\mathrm{Pt}_{2}(\mu-\mathrm{Se})_{2}\left(\mathrm{PPh}_{3}\right)_{4}\right] \mathbf{1 b}[15]$ is less well established, though aspects of the alkylation [16,17] and coordination [18] chemistry of $\left[\mathrm{Pt}_{2}(\mu-\mathrm{Se})_{2}\right.$. - $\left.\left(\mathrm{PPh}_{3}\right)_{4}\right]$ have been briefly investigated. The relative lack of studies on $\left[\mathrm{Pt}_{2}\left(\mu-\mathrm{Se}_{2}\left(\mathrm{PPh}_{3}\right)_{4}\right]\right.$ is noteworthy since it has shown some different reactivity to the sulfide analogue, such as metal-scrambling reactions [19], metal-chalcogen bond cleavage leading to the synthesis of organoselenoethers [20 ], and the synthesis of interesting metal-selenide aggregates [21].

To date, there are no reports of the reactivity of $\left[\mathrm{Pt}_{2}(\mu-\mathrm{Se})_{2}\left(\mathrm{PPh}_{3}\right)_{4}\right]$ towards arylating reagents leading to arylselenolate complexes. Complexes of selenolate ligands have been extensively studied, including dinuclear complexes with bridging selenolate ligands [22 ]. In light of the perceived undesirability of handling organoselenols such as $\mathrm{PhSeH}$ due to their toxicity, air-sensitivity and disagreeable stench, we have investigated the arylation chemistry of $\left[\mathrm{Pt}_{2}(\mu-\mathrm{Se})_{2}\left(\mathrm{PPh}_{3}\right)_{4}\right]$ as a convenient route for the synthesis of dinuclear platinum complexes containing the phenylselenolate ligand.

\section{EXPERIMENTAL}

Materials and methods. Electrospray mass spectra were recorded in a dichloromethanemethanol solution using a Bruker MicrOTOF instrument, periodically calibrated using sodium formate, and employing a capillary exit voltage of $150 \mathrm{~V}$ for routine spectra, but higher voltages to inves-

(C) Fortney-Zirker R.G., Henderson W., Nicholson B.K., 2015 
tigate fragmentation behaviour. ${ }^{31} \mathrm{P}\left\{{ }^{1} \mathrm{H}\right\}$ NMR spectra were recorded on a Bruker Avance spectrometer operating at $162 \mathrm{MHz}$, and the spectra were referenced relative to external $\mathrm{H}_{3} \mathrm{PO}_{4}$. UV-visible spectra were recorded in a $\mathrm{CH}_{2} \mathrm{Cl}_{2}$ solution on a Perkin Elmer Lambda 11 spectrophotometer. $\left[\mathrm{Pt}_{2}(\mu-\right.$ $\mathrm{Se})_{2}\left(\mathrm{PPh}_{3}\right)_{4}$ ] [23] and $\mathrm{Ph}_{2} \mathrm{IBr}\left[24\right.$ ] were prepared by the literature procedures. $\mathrm{NH}_{4} \mathrm{PF}_{6}$ was used as supplied by Aldrich. Reactions were carried out in a reagent grade methanol solvent, without additional purification or precautions to exclude air, light or moisture.

Preparation. $\left[\mathrm{Pt}_{2}(\mu-\mathrm{Se})_{2}\left(\mathrm{PPh}_{3}\right)_{4}\right](315 \mathrm{mg}, 0.197 \mathrm{mmol})$ and $\mathrm{Ph}_{2} \mathrm{IBr}(76 \mathrm{mg}, 0.211 \mathrm{mmol})$ were suspended in methanol $(35 \mathrm{ml})$ and the mixture was stirred at room temperature for $72 \mathrm{~h}$, giving a clear deep orange-brown solution. After filtration to remove traces of insoluble matter, $\mathrm{NH}_{4} \mathrm{PF}_{6}$ (400 $\mathrm{mg}, 2.45 \mathrm{mmol}$ ) was added to the stirred filtrate, giving an orange-brown precipitate. The solid was filtered, washed with water $(2 \times 5 \mathrm{ml})$ and dried under vacuum to give $2 \cdot \mathrm{PF}_{6}$ as a brown solid (250 mg, $70 \%$ \%). M.p. $>300{ }^{\circ} \mathrm{C}$ (decomp.). UV-vis $\left(\mathrm{CH}_{2} \mathrm{Cl}_{2}\right) \lambda_{\max } 430 \mathrm{~nm}(\mathrm{w}),<360 \mathrm{~nm}(\mathrm{vs}) .{ }^{31} \mathrm{P}\left\{{ }^{1} \mathrm{H}\right\}$ NMR $\left(\mathrm{CDCl}_{3}\right), \delta 23.6\left(\mathrm{~m},{ }^{1} J(\mathrm{PtP}) 3320 \mathrm{~Hz}, \mathrm{PPh}_{3}\right.$ trans to $\left.\mathrm{SePh}\right)$ and $23.5\left(\mathrm{~m},{ }^{1} J(\mathrm{PtP}) 2740 \mathrm{~Hz}, \mathrm{PPh}_{3}\right.$ trans to Se). ESI MS (positive ion), $m / z$ 1675.17.

Structure determination. The compound was recrystallised from chloroform-diethyl ether, giving dark orange-brown single crystals of the tris-chloroform solvate suitable for an X-ray diffraction study. Found: C 46.24, H 3.14. $\mathrm{C}_{78} \mathrm{H}_{65} \mathrm{~F}_{6} \mathrm{P}_{5} \mathrm{Pt}_{2} \mathrm{Se}_{2} \cdot 3 \mathrm{CHCl}_{3}$ requires $\mathrm{C} 44.66, \mathrm{H} 3.15 \%$. Crystal data are summarised in Table 1. Data were collected on a Bruker SMART CCD diffractometer and processed using the standard software. Absorption corrections were carried out using SADABS [25]. The structure was solved using SHELX-97 and refined on $F^{2}$ using SHELXL-97 [26] operated under WinGX [27]. All non-hydrogen atoms were treated anisotropically and hydrogen atoms were included with a riding model with $d(\mathrm{C}-\mathrm{H}) 0.95 \AA, U_{\text {iso }}=1.2 U_{\text {eq }}(\mathrm{C})$ for aromatic hydrogen atoms. The complex crys-

Crystal data and structure refinement details for $\left[\mathrm{Pt}_{2}(\mu-\mathrm{Se})(\mu-\mathrm{SePh})\left(\mathrm{PPh}_{3}\right)_{4}\right] \mathrm{PF}_{6} \cdot 3 \mathrm{CHCl}_{3}\left(2 \cdot \mathrm{PF}_{6} \cdot 3 \mathrm{CHCl}_{3}\right)$

Empirical formula
Formula weight
Crystal system
Space group
Unit cell dimensions $a, b, c, \AA$;
Temperature, $\mathrm{K}$
Volume, $\AA^{3}$
$Z$
Density (calculated), g/cm ${ }^{3}$
Absorption coefficient, $\mathrm{mm}^{-1}$
$F(000)$
Crystal size, mm
Collected / Independent reflections
Absorption correction
Max. and min. transmission
Refinement method
Data / restraints / parameters
Goodness-of-fit on $F^{2}$
Final $R$ indices $[I>2 \sigma(I)]$
$R$ indices (all data)
Largest diff. peak and hole, e/ $\AA^{3}$

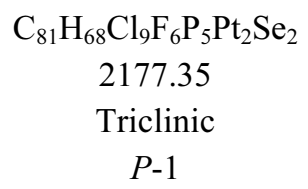

Full-matrix least-squares on $F^{2}$ 20046 / 54 / 971 1.012

$$
\begin{aligned}
R_{1}= & 0.0536, w R_{2}=0.1040 \\
R_{1}= & 0.0975, w R_{2}=0.1183 \\
& 1.677 \text { and }-1.828
\end{aligned}
$$


tallises with three $\mathrm{CHCl}_{3}$ molecules; one $\mathrm{CHCl}_{3}$ was very disordered so the $\mathrm{H}$ atom was not included in the refinement, and $\mathrm{Cl}$ atoms were treated as partial $\mathrm{Cl}$ atoms over 8 sites. The $\mathrm{F}$ atoms of the $\mathrm{PF}_{6}^{-}$ ion and the other $\mathrm{Cl}$ atoms were restrained using the ISOR command in SHELX, to provide better ellipsoids.

A CIF-file containing complete information on the studied structure was deposited with CCDC, deposition number 951013, and is freely available from the web page http://www.ccdc.cam.ac.uk/data_request/cif.

\section{RESULTS AND DISCUSSION}

The reaction of $\left[\mathrm{Pt}_{2}\left(\mu-\mathrm{Se}_{2}\left(\mathrm{PPh}_{3}\right)_{4}\right]\right.$ with diphenyliodonium bromide $\left(\mathrm{Ph}_{2} \mathrm{IBr}\right)$ proceeded smoothly in a methanol suspension following the methodology previously reported for the phenylthiolate complex $\left[\mathrm{Pt}_{2}(\mu-\mathrm{S})(\mu-\mathrm{SPh})\left(\mathrm{PPh}_{3}\right)_{4}\right]^{+}[8]$, giving an orange-brown solution containing the mono-arylated $\left[\mathrm{Pt}_{2}(\mu-\mathrm{Se})(\mu-\mathrm{SePh})\left(\mathrm{PPh}_{3}\right)_{4}\right]^{+}$cation. The complex was isolated as a brown microcrystalline solid $\left[\mathrm{Pt}_{2}(\mu-\mathrm{Se})(\mu-\mathrm{SePh})\left(\mathrm{PPh}_{3}\right)_{4}\right] \mathrm{PF}_{6} \cdot \mathbf{2} \cdot \mathrm{PF}_{6}$ by the addition of excess $\mathrm{NH}_{4} \mathrm{PF}_{6}$, and the synthesis is summarised in Scheme 1. To date, the only complexes with singly derivatised $\left\{\mathrm{Pt}_{2}(\mu-\mathrm{Se})(\mu-\mathrm{SeR})\right\}$ cores have $\mathrm{R}=\mathrm{Me}, n$ - $\mathrm{Bu}$ or $\mathrm{CH}_{2} \mathrm{C}_{6} \mathrm{H}_{4} \mathrm{CH}_{2} \mathrm{Cl}-p$ [16] so the arylation reaction described here extends the range of the known derivatives to include the first arylselenolate derivatives.

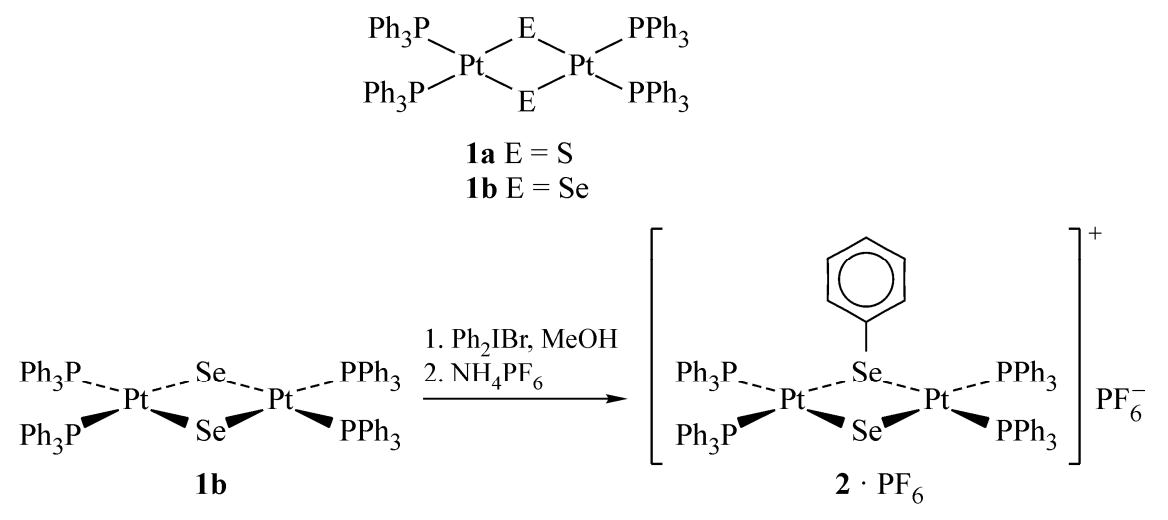

Scheme 1. Synthesis and isolation of $\left[\mathrm{Pt}_{2}(\mu-\mathrm{Se})(\mu-\mathrm{SePh})\left(\mathrm{PPh}_{3}\right)_{4}\right] \mathrm{PF}_{6}\left(\mathbf{2} \cdot \mathrm{PF}_{6}\right)$

The attempted reaction of $\left[\mathrm{Pt}_{2}\left(\mu-\mathrm{Se}_{2}\left(\mathrm{PPh}_{3}\right)_{4}\right]\right.$ with an excess of $\mathrm{Ph}_{2} \mathrm{IBr}$ in methanol for $16 \mathrm{~h}$, followed by the analysis of the reaction mixture by positive-ion ESI MS, gave only 2 , plus the unreacted diphenyliodonium cation, and its aggregate ions $\left(\mathrm{Ph}_{2} \mathrm{I}^{+} \mathrm{m} / z\right.$ 280.95, $\left(\mathrm{Ph}_{2} \mathrm{I}\right)_{2} \mathrm{Br}^{+} \mathrm{m} / z$ 642.84, $\left(\mathrm{Ph}_{2} \mathrm{I}\right)_{3} \mathrm{Br}_{2}^{+}$ $m / z$ 1002.72, $\left(\mathrm{Ph}_{2} \mathrm{I}\right)_{4} \mathrm{Br}_{3}^{+} \mathrm{m} / \mathrm{z}$ 1364.61) with no evidence for the doubly-phenylated complex $\left[\mathrm{Pt}_{2}(\mu-\right.$ $\left.\mathrm{SePh})_{2}\left(\mathrm{PPh}_{3}\right)_{4}\right]^{2+}$. The same behaviour was observed for the sulfide analogue $\left[\mathrm{Pt}_{2}(\mu-\mathrm{S})_{2}\left(\mathrm{PPh}_{3}\right)_{4}\right][8]$.

Complex $2 \cdot \mathrm{PF}_{6}$ was characterised by ${ }^{31} \mathrm{P}\left\{{ }^{1} \mathrm{H}\right\}$ NMR spectroscopy, ESI mass spectrometry, and an $\mathrm{X}$-ray crystallographic study. The ${ }^{31} \mathrm{P}\left\{{ }^{1} \mathrm{H}\right\} \mathrm{NMR}$ spectrum of $\mathbf{2} \cdot \mathrm{PF}_{6}$ in $\mathrm{CDCl}_{3}$ showed (in addition to the expected multiplet for the $\mathrm{PF}_{6}^{-}$anion) two complex multiplet resonances for the $\mathrm{PPh}_{3}$ ligands at $\delta$ 23.6 and 23.5 due to the two inequivalent types of $\mathrm{PPh}_{3}$ ligands, trans to $\mathrm{SePh}$ or Se respectively. Coupling to ${ }^{195} \mathrm{Pt}$ produced distinctive satellites, and the value of ${ }^{1} \mathrm{~J}(\mathrm{PtP})$ for the phosphines trans to selenide is approximately $2740 \mathrm{~Hz}$, while that for the phosphines trans to $\mathrm{SePh}$ is approximately $3320 \mathrm{~Hz}$, due to the lower trans-influence [28 ] of a SePh group compared to selenide. These coupling constants are both smaller than the corresponding values for $\left[\mathrm{Pt}_{2}(\mu-\mathrm{S})(\mu-\mathrm{SPh})\left(\mathrm{PPh}_{3}\right)_{4}\right]^{+}(2613 \mathrm{~Hz}$ and $3291 \mathrm{~Hz}$ ) [ 8 ], indicating the selenium ligands to have slightly lower trans-influences than their sulfur counterparts. The UV-visible spectrum of a brown solution of $2 \cdot \mathrm{PF}_{6}$ in $\mathrm{CH}_{2} \mathrm{Cl}_{2}$ showed an intense charge-transfer absorption at $<360 \mathrm{~nm}$, with a low intensity shoulder centred at $430 \mathrm{~nm}$. The bright yellow sulfur analogue $\left[\mathrm{Pt}_{2}(\mu-\mathrm{S})(\mu-\mathrm{SPh})\left(\mathrm{PPh}_{3}\right)_{4}\right] \mathrm{PF}_{6}$ also showed an intense charge transfer absorption at $<360 \mathrm{~nm}$, but the shoulder at $420 \mathrm{~nm}$ in this case was much better resolved. 
Fig. 1. Comparison of $(a)$ the experimental (from positive-ion ESI mass spectrum) and (b) calculated isotope patterns for $\left[\mathrm{Pt}_{2}(\mu-\mathrm{Se})(\mu-\right.$ $\left.\mathrm{SePh})\left(\mathrm{PPh}_{3}\right)_{4}\right]^{+}$ion $2(\mathrm{~m} / \mathrm{z} 1675.17$ for the most intense peak in the isotope pattern)
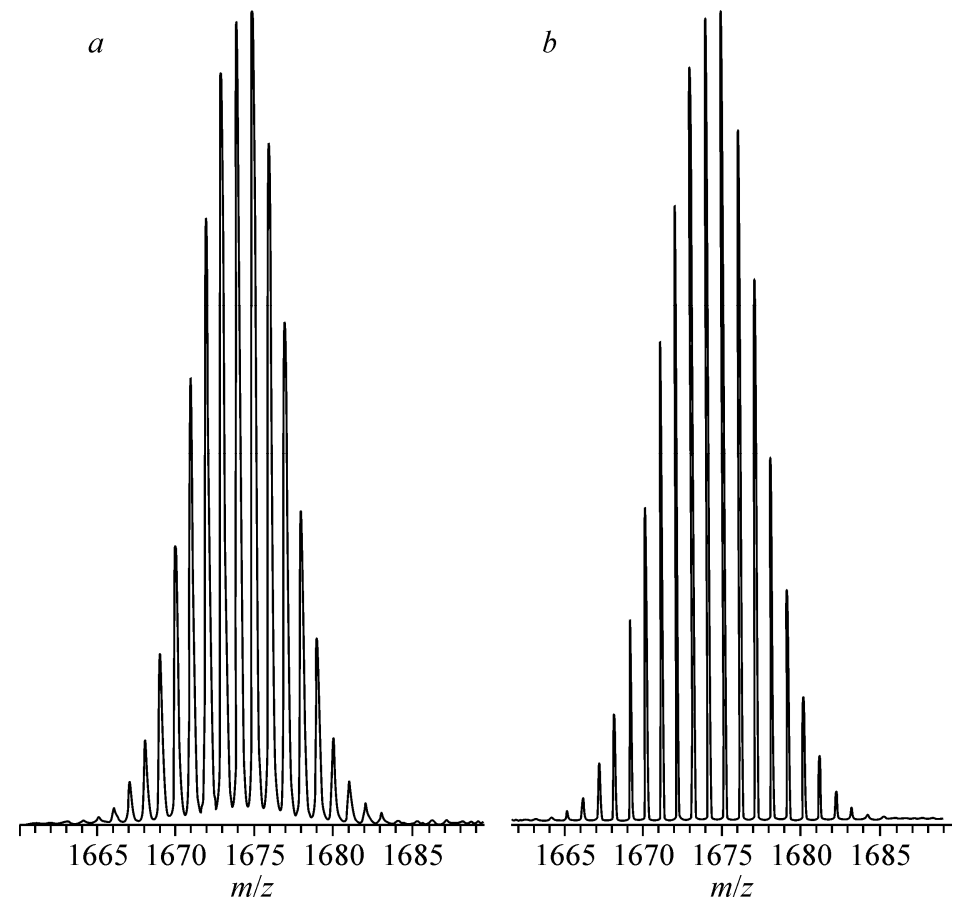

The positive-ion ESI mass spectrum of $\mathbf{2} \cdot \mathrm{PF}_{6}$ at a capillary exit voltage of $150 \mathrm{~V}$ showed a single dominant peak at $\mathrm{m} / \mathrm{z} 1675.17$ (calculated $\mathrm{m} / \mathrm{z}$ 1675.17), with an isotope pattern that showed good agreement with the calculated pattern (Fig. 1). The fragmentation behaviour of $\mathbf{2}$ was investigated by increasing the capillary exit voltage. At $180 \mathrm{~V}$ there was no observed fragmentation, but at $210 \mathrm{~V}$ several fragment ions were observed and assigned as $\left[\mathrm{Pt}_{2}(\mu-\mathrm{Se})(\mu-\mathrm{SePh})\left(\mathrm{PPh}_{3}\right)_{3}\right]^{+}(\mathrm{m} / z$ 1413.08, from loss of $\left.\mathrm{PPh}_{3}\right),\left[\mathrm{Pt}_{2}(\mu-\mathrm{Se})(\mu-\mathrm{SePh})\left(\mathrm{PPh}_{3}\right)_{2}\right]^{+}\left(m / z\right.$ 1150.98, from loss of $\left.2 \mathrm{PPh}_{3}\right),\left[\mathrm{Pt}(\mathrm{SePh})\left(\mathrm{PPh}_{3}\right)_{2}\right]^{+}(\mathrm{m} / z$ 877.80, from fragmentation of the $\mathrm{Pt}_{2} \mathrm{Se}_{2}$ core $)$, and $\left[\mathrm{Pt}\left(\mathrm{PPh}_{3}\right)\left(\mathrm{Ph}_{2} \mathrm{PC}_{6} \mathrm{H}_{4}\right)\right]^{+}(\mathrm{m} / z$ 718.14, from cyclometallation of a $\mathrm{PPh}_{3}$ ligand) [29]. Numerous very low intensity ions were also observed at $m / z<1100$, but were not assigned. The spectra of the thiolate analogue $\left[\mathrm{Pt}_{2}(\mu-\mathrm{S})(\mu-\mathrm{SPh})\left(\mathrm{PPh}_{3}\right)_{4}\right]^{+}$ were recorded under analogous conditions; while the overall features were fairly similar with the parent cation base peak in both cases, the formation of $\left[\mathrm{Pt}(\mathrm{SePh})\left(\mathrm{PPh}_{3}\right)_{2}\right]^{+}$and $\left[\mathrm{Pt}_{2}(\mu-\mathrm{Se})(\mu-\mathrm{SePh})\right.$. $\left.\cdot\left(\mathrm{PPh}_{3}\right)_{2}\right]^{+}$were not paralleled in the sulfur system under these conditions.

ESI mass spectrometry has also been used to demonstrate that the metalloligand coordination chemistry of $\left[\mathrm{Pt}_{2}(\mu-\mathrm{Se})(\mu-\mathrm{SePh})\left(\mathrm{PPh}_{3}\right)_{4}\right]^{+}$is analogous to the related systems such as $\left[\mathrm{Pt}_{2}(\mu-\mathrm{S})(\mu-\right.$ $\left.\mathrm{SPh})\left(\mathrm{PPh}_{3}\right)_{4}\right]^{+}$. Mono-derivatised $\left[\mathrm{Pt}_{2}(\mu-\mathrm{S})(\mu-\mathrm{SR})\left(\mathrm{PPh}_{3}\right)_{4}\right]^{+}$complexes have been shown to act as metalloligands to metal centres (gold(I) or mercury(II)) through the underivatised sulfide ligand $[8,30]$. Mass spectrometry-monitored micro-scale reaction of $2 \cdot \mathrm{PF}_{6}$ with $\mathrm{Ph}_{3} \mathrm{PAuCl}$ gave the $\left[\mathrm{Pt}_{2}(\mu-\right.$ $\left.\left.\mathrm{SeAuPPh}_{3}\right)(\mu-\mathrm{SePh})\left(\mathrm{PPh}_{3}\right)_{4}\right]^{2+}$ ion at $m / z 1066.88$ (calculated $m / z$ 1067.11) and the reaction with organomercury chlorides $\mathrm{RHgCl}(\mathrm{R}=\mathrm{Ph}$ or ferrocenyl $=\mathrm{Fc})$ gave $\left[\mathrm{Pt}_{2}(\mu-\mathrm{SeHgFc})(\mu-\mathrm{SePh})\left(\mathrm{PPh}_{3}\right)_{4}\right]^{2+}$ at $m / z$ 1029.85 (calculated $m / z$ 1030.07) and $\left[\mathrm{Pt}_{2}(\mu-\mathrm{SeHgPh})(\mu-\mathrm{SePh})\left(\mathrm{PPh}_{3}\right)_{4}\right]^{2+}$ at $m / z 975.88($ calculated $m / z$ 976.09).

Since the previously reported X-ray crystal structure of the sulfur analogue $\left[\mathrm{Pt}_{2}(\mu-\mathrm{S})(\mu-\mathrm{SPh})\right.$. . $\left.\left(\mathrm{PPh}_{3}\right)_{4}\right]^{+}$was disordered [8], the structure of $\left[\mathrm{Pt}_{2}(\mu-\mathrm{Se})(\mu-\mathrm{SePh})\left(\mathrm{PPh}_{3}\right)_{4}\right] \mathrm{PF}_{6} 2$ was determined. Selected bond lengths and angles are given in Table 2. The structure of the core of cation $\mathbf{2}$ is shown in Fig. 2, which confirms the structure as a dinuclear platinum complex with bridging selenido and phenylselenolato ligands. The four-membered $\left\{\mathrm{Pt}_{2} \mathrm{Se}_{2}\right\}$ ring is slightly puckered, with a dihedral angle $\theta$ between the two $\mathrm{PtSe}_{2}$ planes of $164.87^{\circ}$. This can be compared to the corresponding $\theta$ angle of $146.33^{\circ}$ in the (more puckered) sulfur complex $\left[\mathrm{Pt}_{2}(\mu-\mathrm{S})(\mu-\mathrm{SPh})\left(\mathrm{PPh}_{3}\right)_{4}\right]^{+}[8]$ and the fully planar $\left(\theta=180^{\circ}\right)$ parent selenide $\left[\mathrm{Pt}_{2}\left(\mu-\mathrm{Se}_{2}\left(\mathrm{PPh}_{3}\right)_{4}\right]\right.$ [ 15]. The four-membered ring in 2 is markedly less 


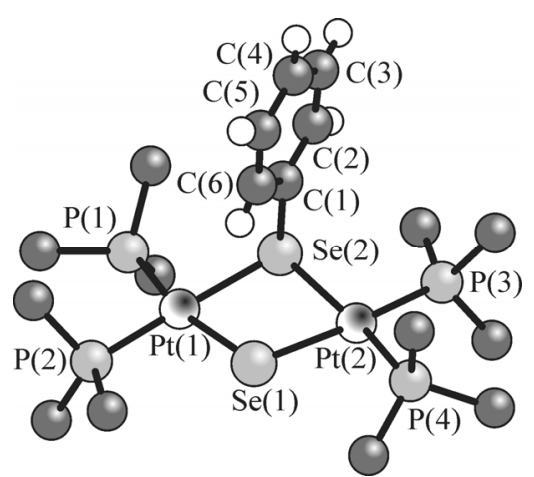

Fig. 2. Structure of the core of the $\left[\mathrm{Pt}_{2}(\mu-\mathrm{Se})(\mu-\mathrm{SePh})\right.$. $\left.\cdot\left(\mathrm{PPh}_{3}\right)_{4}\right] \mathrm{PF}_{6} \cdot 3 \mathrm{CHCl}_{3}$ complex showing the atom numbering scheme; only ipso carbon atoms of the four triphenylphosphine ligands are shown, and the $\mathrm{PF}_{6}^{-}$counterion and $\mathrm{CHCl}_{3}$ molecules of crystallisation are omitted for clarity

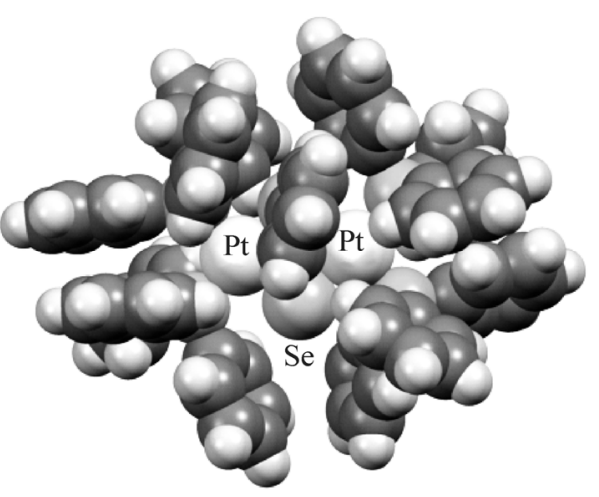

Fig. 3. Space-filling view of $\left[\mathrm{Pt}_{2}(\mu-\mathrm{Se})(\mu-\right.$ $\left.\mathrm{SePh})\left(\mathrm{PPh}_{3}\right)_{4}\right]^{+}$cation 2, showing the twisting of the SePh ring and the $\pi-\pi$ interaction between $\mathrm{SePh}$ phenyl and phenyl on a triphenylphosphine ligand

T a b l e 2

Selected bond lengths $(\AA)$ and angles (deg.) for $\left[\mathrm{Pt}_{2}(\mu-\mathrm{Se})(\mu-\mathrm{SePh})\left(\mathrm{PPh}_{3}\right)_{4}\right] \mathrm{PF}_{6} \cdot 3 \mathrm{CHCl}_{3}\left(\mathbf{2} \cdot \mathrm{PF}_{6} \cdot 3 \mathrm{CHCl}_{3}\right)$

\begin{tabular}{l|l|l|r||l|r}
\hline $\mathrm{Pt}(1)-\mathrm{P}(2)$ & $2.3256(19)$ & $\mathrm{P}(2)-\mathrm{Pt}(1)-\mathrm{P}(1)$ & $99.37(7)$ & $\mathrm{P}(4)-\mathrm{Pt}(2)-\mathrm{P}(3)$ & $100.49(7)$ \\
$\mathrm{Pt}(1)-\mathrm{Se}(1)$ & $2.4918(8)$ & $\mathrm{P}(2)-\mathrm{Pt}(1)-\mathrm{Se}(1)$ & $92.80(5)$ & $\mathrm{P}(1)-\mathrm{Pt}(1)-\mathrm{Se}(1)$ & $167.75(5)$ \\
$\mathrm{Pt}(2)-\mathrm{P}(4)$ & $2.3421(19)$ & $\mathrm{P}(2)-\mathrm{Pt}(1)-\mathrm{Se}(2)$ & $172.35(5)$ & $\mathrm{P}(1)-\mathrm{Pt}(1)-\mathrm{Se}(2)$ & $86.85(5)$ \\
$\mathrm{Pt}(2)-\mathrm{Se}(2)$ & $2.5095(8)$ & $\mathrm{P}(4)-\mathrm{Pt}(2)-\mathrm{Se}(2)$ & $163.68(5)$ & $\mathrm{P}(3)-\mathrm{Pt}(2)-\mathrm{Se}(2)$ & $91.59(5)$ \\
$\mathrm{Se}(2)-\mathrm{C}(1)$ & $2.018(9)$ & $\mathrm{P}(4)-\mathrm{Pt}(2)-\mathrm{Se}(1)$ & $87.82(5)$ & $\mathrm{P}(3)-\mathrm{Pt}(2)-\mathrm{Se}(1)$ & $171.39(5)$ \\
$\mathrm{Pt}(1)-\mathrm{P}(1)$ & $2.3403(18)$ & $\mathrm{Se}(1)-\mathrm{Pt}(1)-\mathrm{Se}(2)$ & $81.12(2)$ & $\mathrm{Se}(2)-\mathrm{Pt}(2)-\mathrm{Se}(1)$ & $80.69(2)$ \\
$\mathrm{Pt}(1)-\mathrm{Se}(2)$ & $2.5217(8)$ & $\mathrm{Pt}(1)-\mathrm{Se}(1)-\mathrm{Pt}(2)$ & $98.11(3)$ & $\mathrm{Pt}(2)-\mathrm{Se}(2)-\mathrm{Pt}(1)$ & $97.76(3)$ \\
$\mathrm{Pt}(2)-\mathrm{P}(3)$ & $2.3510(19)$ & $\mathrm{C}(1)-\mathrm{Se}(2)-\mathrm{Pt}(2)$ & $96.6(3)$ & $\mathrm{C}(1)-\mathrm{Se}(2)-\mathrm{Pt}(1)$ & $102.6(3)$ \\
$\mathrm{Pt}(2)-\mathrm{Se}(1)$ & $2.5261(8)$ & & & &
\end{tabular}

puckered than the corresponding methylselenolate complex $\left[\mathrm{Pt}_{2}(\mu-\mathrm{Se})(\mu-\mathrm{SeMe})\left(\mathrm{PPh}_{3}\right)_{4}\right]^{+}$for which $\theta=133.6^{\circ}[16]$. The geometry about the two platinum centres is only slightly distorted from the regular square-planar geometry, with $\tau_{4}$ parameters (as defined by Houser et al [31 ]) of 0.14 and 0.18 for $\mathrm{Pt}(1)$ and $\mathrm{Pt}(2)$ respectively, indicating that $\mathrm{Pt}(1)$ is closest to square-planar (theoretical $\tau_{4}=0.00$ ).

The phenylselenolate ligand adopts an exo position in a 'pocket' bound by the $\mathrm{PPh}_{3}$ ligands, with the $\mathrm{Se}-\mathrm{C}$ bond 'perpendicular' to the $\left\{\mathrm{Pt}_{2} \mathrm{Se}_{2}\right\}$ ring. The phenyl ring is not coplanar with the $\mathrm{Se} \cdots \mathrm{Se}$ vector, but is instead twisted, as can be seen in Fig. 2 and the space-filling plan diagram in Fig. 3; the $\mathrm{Se} \cdots \mathrm{Se}-\mathrm{C}-\mathrm{C}$ torsion angle is approximately $18^{\circ}$. As can be seen in Fig. 3, the phenylselenolate aromatic ring appears to be involved in a weak $\pi-\pi$ interaction with a phenyl ring on $\mathrm{P}(1)$ phosphorus (ring $\mathrm{C}(121)$ to $\mathrm{C}(126)$ ), the interplanar angle between the two rings being $4.05^{\circ}$, and the distance between the two ring centroids being $3.785 \AA$.

In conclusion, through a facile phenylation reaction using diphenyliodonium bromide, it has been possible to convert the selenido complex $\left[\mathrm{Pt}_{2}(\mu-\mathrm{Se})_{2}\left(\mathrm{PPh}_{3}\right)_{4}\right]$ into the phenylselenolate complex $\left[\mathrm{Pt}_{2}(\mu-\right.$ $\left.\mathrm{Se})(\mu-\mathrm{SePh})\left(\mathrm{PPh}_{3}\right)_{4}\right]^{+}$, which has been fully characterised. The structural determination on the complex indicates a significantly flatter metallacycle compared to the sulfur analogue, with NMR spectroscopy indicating that the selenium ligands have slightly lower trans influences. These results suggest that the designer synthesis of a range of arylselenolate ligands on a diplatinum framework could be possible using an extension of this methodology.

The University of Waikato is acknowledged for financial support of this work, Pat Gread for assistance with mass spectrometry, and Dr. Tania Groutso (University of Auckland) for collection of 
X-ray data. W. Henderson thanks Prof. Paul Low (University of Durham) for generously providing facilities for the writing of this manuscript. We thank the Cambridge Crystallographic Data Centre for the Mercury program used for displaying the X-ray structure in this paper.

\section{REFERENCES}

1. Fong S.-W.A., Hor T.S.A. // J. Chem. Soc. Dalton Trans. - 1999. - P. 639.

2. González-Duarte P., Lledós A., Mas-Ballesté R. // Eur. J. Inorg. Chem. - 2004. - P. 3585.

3. Mas-Ballesté R., Aullón G., Champkin P.A., Clegg W., Mégret C., González-Duarte P., Lledós A. // Chem. Eur. J. - 2003. - 9. - P. 5023.

4. Novio F., Mas-Ballesté R., Gallardo I., González-Duarte P., Lledós A., Vila N. // Dalton Trans. - 2005. - P. 2742; Jeram S., Henderson W., Nicholson B.K., Hor T.S.A. // J. Organomet. Chem. - 2006. - 691. - P. 2827.

5. Chatt J., Mingos D.M.P. // J. Chem. Soc. A. - 1970. - P. 1243; Ugo R., La Monica G., Cenini S., Segre A., Conti F. // J. Chem. Soc. A. - 1971. - P. 522.

6. Henderson W., Chong S.H., Hor T.S.A. // Inorg. Chim. Acta. - 2006. - 359. - P. 3440.

7. Nova A., Mas-Ballesté R., Ujaque G., González-Duarte P., Lledós A. // Chem. Cmmun. - 2008. - P. 3130.

8. Deadman B.J., Henderson W., Nicholson B.K., Petchell L.E., Rose S.L., Hor T.S.A. // Inorg. Chim. Acta. - 2010. - 363. - P. 637.

9. Nova A., Mas-Ballesté R., Ujaque G., González-Duarte P., Lledós A. // Dalton Trans. - 2009. - P. 5980.

10. Li J., Koh L.L., Hor T.S.A. // Chem. Commun. - 2009. - P. 3416.

11. Mas-Ballesté R., Capdevila M., González-Duarte P., Hamidi M., Lledós A., Mégret C., de Montauzon D. // Dalton Trans. - 2004. - P. 706.

12. Ruiz J., Rodríguez V., Pérez A., López G., Bautista D. // J. Organomet. Chem. - 2004. - 689. - P. 2080; Mas-Ballesté R., Clegg W., Lledós A., González-Duarte P. // Eur. J. Inorg. Chem. - 2004. - P. 3223.

13. Li J., Li F., Koh L.L., Hor T.S.A. // Dalton Trans. - 2010. - 39. - P. 2441; Clarke H.M., Henderson W., Nicholson B.K. // Inorg. Chim. Acta. - 2011. - 376. - P. 446; Henderson W., Nicholson B.K., Bridson J.H., Kueh J.T., Hor T.S.A. // Inorg. Chim. Acta. - 2011. - 375. - P. 142.

14. Mas-Ballesté R., Champkin P.A., Clegg W., González-Duarte P., Lledós A., Ujaque G. // Organometallics. -2004. - 23. - P. 2522.

15. Bencini A., Di Vaira M., Morassi R., Stoppioni P., Mele F. // Polyhedron. - 1996. - 15. - P. 2079.

16. Yeo J.S.L., Vittal J.J., Henderson W., Hor T.S.A. // Organometallics. - 2002. - 21. - P. 2944.

17. Devoy S.M., Henderson W., Nicholson B.K., Hor T.S.A. // Inorg. Chim. Acta. - 2009. - 362. - P. 1194.

18. Yeo J.S.L., Vittal J.J., Henderson W., Hor T.S.A. // J. Chem. Soc. Dalton Trans. - 2002. - P. 328.

19. Yeo J.S.L., Vittal J.J., Henderson W., Hor T.S.A. // Inorg. Chem. - 2002. - 41. - P. 1194.

20. Yeo J.S.L., Vittal J.J., Hor T.S.A. // Eur. J. Inorg. Chem. - 2003. - P. 277.

21. Yeo J.S.L., Vittal J.J., Henderson W., Hor T.S.A. // J. Organomet. Chem. - 2002. - 659. - P. 92.

22. Jain V.K., Kannan S. // J. Organomet. Chem. - 1991. - 405. - P. 265; Jain V.K., Kannan S., Butcher R.J., Jasinski J.P. // J. Organomet. Chem. - 1994. - 468. - P. 285; Jain V.K., Kannan S., Butcher R.J., Jasinski J.P. // Polyhedron. - 1995. - 14. - P. 3641; Dey S., Jain V.K., Varghese B. // J. Organomet. Chem. - 2001. - 623. - P. 48; Oilunkaniemi R., Laitinen R.S., Ahlgrén M. // J. Organomet. Chem. - 2001. - 623. - P. 168; Brown M.J., Corrigan J.F. // J. Organomet. Chem. - 2004. - 689. - P. 2872; Kumbhare L.B., Jain V.K., Phadnis P.P., Nethaji M. // J. Organomet. Chem. - 2007. - 692. - P. 1546; Kumbhare L.B., Wadawale A.P., Jain V.K., Kolay S., Nethaji M. // J. Organomet. Chem. - 2009. - 694. - P. 3892; Oilunkaniemi R., Laitinen R.S., Ahlgrén M. // J. Organomet. Chem. - 1999. - 587. - P. 200; Singhala A., Jain V.K., Varghese B., Tiekink E.R.T. // Inorg. Chim. Acta. - 1999. - 285. - P. 190; Fuller A.L., Knight F.R., Slawin A.M.Z., Woollins J.D. // Eur. J. Inorg. Chem. - 2010. - P. 4034.

23. Yeo J.S.L., Vittal J.J., Henderson W., Hor T.S.A. // J. Chem. Soc. Dalton Trans. - 2001. - P. 315.

24. Beringer F.M., Drexler M., Gindler E.M., Lumpkin C.C. // J. Am. Chem. Soc. - 1953. - 75. - P. 2705.

25. Blessing R.H. // Acta Crystallogr. - 1995. - A51. - P. 33.

26. Sheldrick G.M. SHELXS-97, SHELXL-97, Universität Göttingen, Germany, 1997.

27. Farrugia L.J. // J. Appl. Crystallogr. - 1999. - 32. - P. 837.

28. Appleton T.G., Clark H.C., Manzer L.E. // Coord. Chem. Rev. - 1973. - 10. - P. 335.

29. McCaffrey L.J., Henderson W., Nicholson B.K., Mackay J.E., Dinger M.B. // J. Chem. Soc. Dalton Trans. - 1997. - P. 2577.

30. Henderson W., G.C. Saunders, Hor T.S.A. // Inorg. Chim. Acta. - 2011. - 368. - P. 6; Henderson W., Nicholson B.K., Devoy S.M., Hor T.S.A. // Inorg. Chim. Acta. - 2008. - 361. - P. 1908.

31. Yang L., Powell D.R., Houser R.P. // Dalton Trans. - 2007. - P. 955. 